\title{
RHEUMATOID ARTHRITIS AND THE POSITIVE L.E.-CELL PHENOMENON
}

\author{
BY \\ J. H. KIEVITS, J. GOSLINGS, H. R. E. SCHUIT, AND W. HIJMANS \\ Department of Rheumatology, University Hospital, Leiden, Netherlands
}

(RECEIVED FOR PUBLICATION APRiL 23, 1956)

Kaposi (1872) first drew attention to the fact that joint symptoms occur in a great number of cases of systemic lupus erythematosus. Reifenstein, Reifenstein, and Reifenstein (1939) compiled data from eighteen patients and noted articular manifestations in all. Klemperer, Pollack, and Baehr (1941) noticed that in ten out of twenty of their patients joint symptoms were the first manifestations of the disease. In a more recent study, Dubois (1953) mentions that 90 per cent. of a series of 62 patients had joint involvement, ranging from ill-defined arthralgia to joint deformities with bone destruction similar to those seen in rheumatoid arthritis. In this same series, 30 per cent. had "definite rheumatoid deformity". In a group of 105 cases, analysed by Harvey, Shulman, Tumulty, Conley, and Schoenrich (1955), only ten had no joint involvement, and in 63 per cent. the articular manifestations occurred during the initial episode of the illness; the arthritis was described as typical of rheumatoid arthritis in 28 of these patients.

It is now generally accepted that Hargraves's L.E.-cell test (Hargraves, Richmond, and Morton, 1948) is a useful diagnostic method for detecting systemic lupus erythematosus, especially since this test can be positive in an early stage of the disease and also in the mono- or oligosymptomatic phase. If this test could be considered to be absolutely specific, it would then seem possible to diagnose some cases of rheumatoid arthritis as mono- or oligosymptomatic forms of systemic lupus erythematosus.

To investigate this possibility two series of adult patients with rheumatoid arthritis were studied, and the L.E.-cell phenomenon was found to be positive in 17 and 15 per cent. respectively. Statistical analysis of certain signs and symptoms in the patients with and without a positive L.E. phenomenon showed significant differences.

\section{Material and Methods}

Only adults suffering from straightforward rheumatoid arthritis of the peripheral joints, diagnosed on generally accepted clinical criteria, were included. Those whose history and clinical findings were of a dubious nature were excluded, as were also patients with ankylosing spondylitis. The Zimmer and Hargraves (1952) bloodclot technique was used in making L.E.-cell preparations, with the addition of an interval of 10 to 20 minutes between fragmentation of the blood clot and centrifugation. From every patient four preparations were made and stained by the Giemsa method. Each preparation was examined microscopically with a $10 \times$ eyepiece and a $25 \times$ objective lens for at least 15 minutes. All suspected cells were then further examined by oilimmersion magnification. According to the criteria of Hargraves and others (1948), the phagocytosed inclusion bodies were distinguished from other phagocytic phenomena, especially nucleo-phagocytosis. For the purpose of this study a preparation was called positive if one or more L.E. cells or rosettes were seen.

Series A consisted of 388 cases of rheumatoid arthritis, which however did not include all patients available during that period. In order to exclude the unintentional selection of possible cases of lupus erythematosus, Series B comprised one hundred unselected consecutive cases of rheumatoid arthritis as they were admitted to our department. In Series C (controls) the Hargraves test was applied in 54 cases of active tuberculosis, fourteen cases of chronic nephritis, and thirteen cases of active discoid forms of lupus erythematosus. The test was also applied to 444 cases from the Department of 
MATERIAL STUDIED

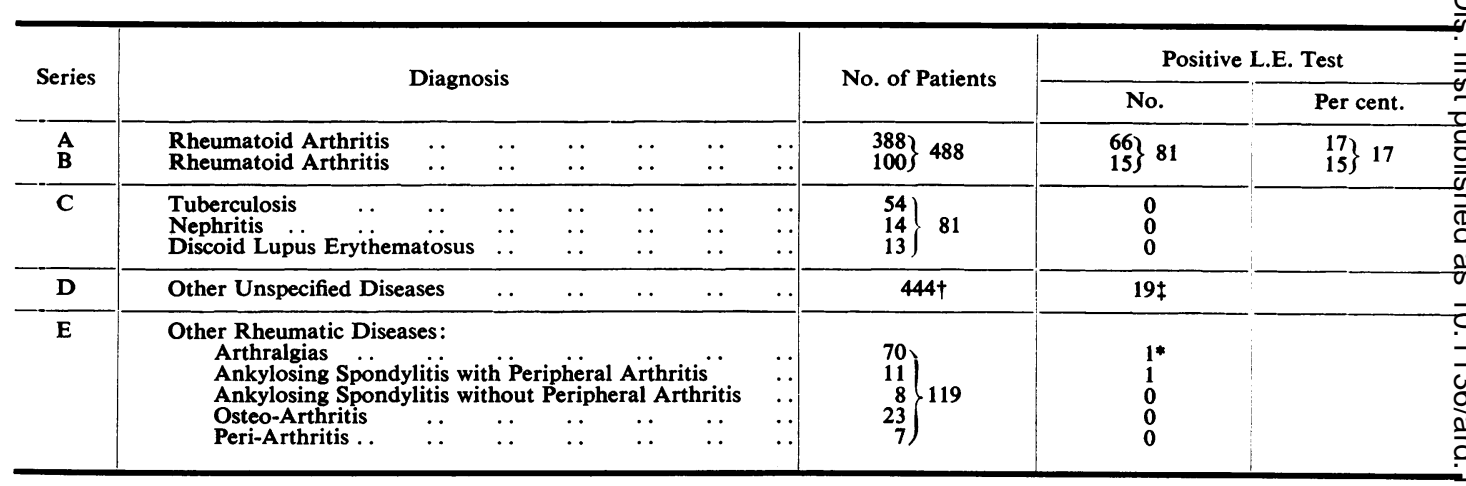

* Who later developed rheumatoid nodules.

\# Eighteen systemic lupus erythematosus and one scleroderma.

Medicine in which the diagnosis was unknown to us (Series D). Furthermore, 119 additional cases of rheumatic disease other than rheumatoid arthritis were studied (Series E).

Various signs and symptoms were analysed statistically in fifty unselected cases of rheumatoid arthritis with positive L.E. phenomenon ( $\mathrm{LE}+$ ) and a hundred consecutive cases of rheumatoid arthritis without positive L.E. phenomenon (LE-).

With the exception of information regarding lower respiratory tract infection, and that regarding erythrocyte sedimentation rate after gold therapy, the data were obtained at the time of the L.E.-cell examination.

\section{Results}

The results of the L.E.-cell examinations are given in Table I. This test was positive in 17 per cent. of the group of 388 cases of rheumatoid arthritis (Series A) and in 15 per cent. of the consecutive series of 100 cases (Series B).

No L.E. cells were seen in the control group of 81 patients, comprising 54 cases of active tuberculosis, fourteen cases of chronic nephritis, and thirteen cases of active discoid lupus erythematosus (Series C).

In the slides of 444 other cases sent to our laboratory by the Department of Medicine, L.E. cells were found in nineteen instances (Series D). In eighteen of these cases, the clinical diagnosis was systemic lupus erythematosus or the findings were compatible with this diagnosis. In one case the patient was suffering from scleroderma.

In 119 cases with a diagnosis of a rheumatic disease other than rheumatoid arthritis (Series E)
† Sent to our department by the Department of Medicine.

L.E. cells were found twice: in one of these, a patient with unclassified arthralgia, rheumatoid nodules $\vec{s}$ developed 3 weeks after the test was done, and the other patient was suffering from ankylosing spondy litis with peripheral arthritis. Both cases therefore showed signs and symptoms compatible with the syndrome of rheumatoid arthritis.

Table II (opposite) indicates which of the sigis and symptoms used in comparing the fifty cases $\mathrm{LE}+$ with the one hundred consecutive cases of LE - showed significant differences.

No differences were found in sex distribution or duration of illness (Table III, opposite).

The results in Table IV (opposite) were analysed $\overrightarrow{\overrightarrow{\hat{\beta}}}$. by the exact method of Fisher (1954) using the $\chi^{2}$ test.

Splenomegaly (Table IV) occurred six times in the $\mathrm{LE}+$ group and only once in the LE - group. On the basis of $P=0 \cdot 006$, the difference is statistically significant:-

Diseases of the Lower Respiratory Tract (Table IV)o were found in fourteen patients, either on clinical or? roentgenological examination or in the previous history ;O nine cases belonged to the LE+ group and five to the LE - group. The difference is statistically significant $(P=0.02)$, but this did not apply when only the chest ${ }^{\mathrm{O}}$ $x$ rays made at the same time as the L.E.-cell test, were $\mathbb{O}$ analysed.

Urinary Sediment (Table IV-excluding cases ofe bacterial origin) occurred with greater frequency in the $\mathbb{\Phi}$ LE + group $(P=0 \cdot 006)$. This was not the case with $\stackrel{?}{+}$ albuminuria. 
TABLE II

CLINICAL SIGNS AND SYMPTOMS IN FIFTY CASES OF LE + COMPARED WITH THOSE IN ONE HUNDRED CONSECUTIVE CASES OF LE-

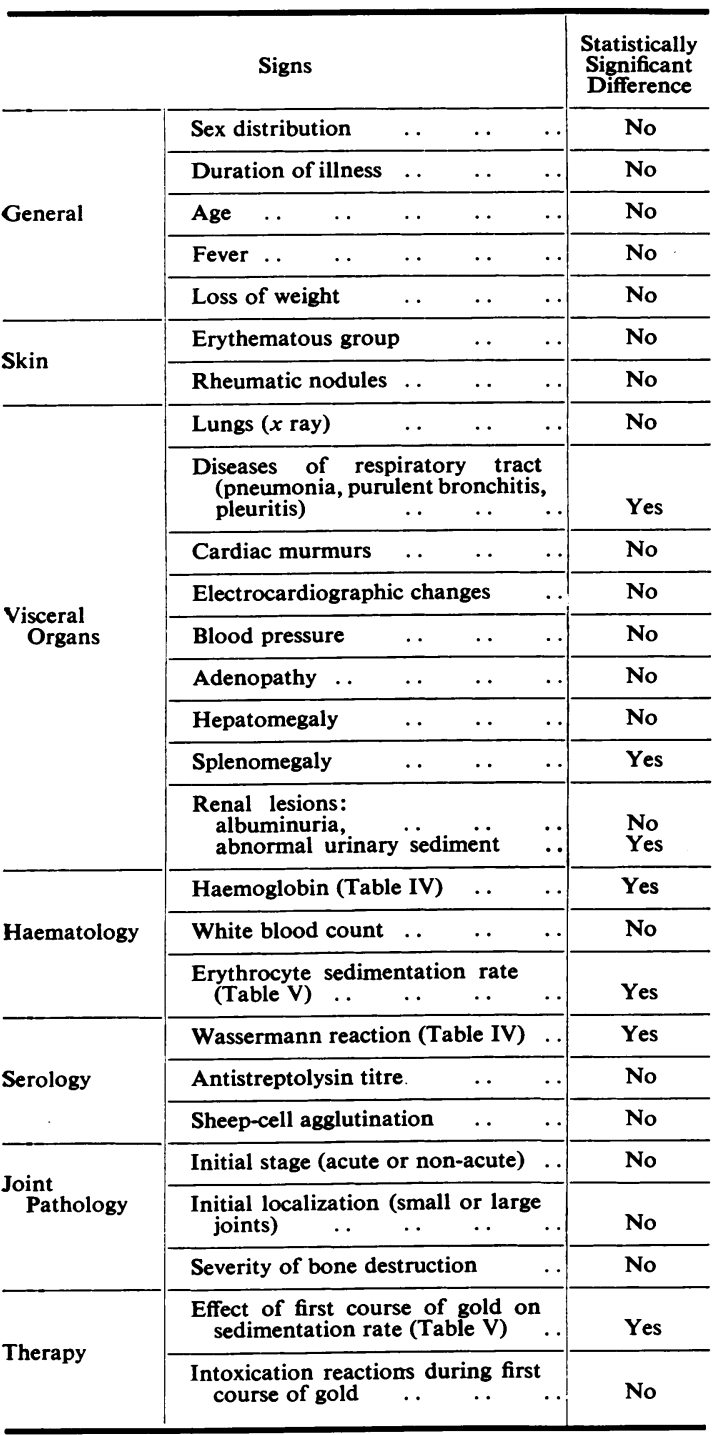

False-Positive Test for Syphilis (Table IV).-A positive Wassermann reaction was found with greater frequency in the LE + group, but, as our attention was drawn to this reaction in a late stage of the study, the number of unknowns is high. On the basis of the known figures, the difference is statistically significant $(P=0.002)$. The Meinicke reaction was negative in six out of the eight cases with a positive Wassermann reaction. It is reasonable to assume that all positive tests were so-called false-positive, as none of these patients had a luetic infection as judged by other routine criteria.
TABLE III

SEX DISTRIBUTION AND DURATION OF ILLNESS

\begin{tabular}{|c|c|c|c|c|}
\hline L.E. Cells & & + & - & Total \\
\hline \multirow[t]{2}{*}{$\begin{array}{c}\text { Duration } \\
\text { (yrs) }\end{array}$} & $\begin{array}{c}<1 \\
1-2 \\
2-3 \\
3-5 \\
5-10 \\
10-20 \\
>20 \\
\text { Unknown }\end{array}$ & $\begin{array}{r}4 \\
7 \\
7 \\
6 \\
13 \\
8 \\
5\end{array}$ & $\begin{array}{r}16 \\
13 \\
7 \\
11 \\
21 \\
24 \\
7 \\
7 \\
1\end{array}$ & $\begin{array}{r}20 \\
20 \\
14 \\
17 \\
34 \\
32 \\
12 \\
1\end{array}$ \\
\hline & Total & 50 & 100 & 150 \\
\hline \multirow[t]{2}{*}{ Sex } & $\begin{array}{ll}\text { Male } & \ldots \\
\text { Female } & \ldots\end{array}$ & $\begin{array}{l}15 \\
35\end{array}$ & $\begin{array}{l}41 \\
59\end{array}$ & $\begin{array}{l}56 \\
94\end{array}$ \\
\hline & Total & 50 & 100 & 150 \\
\hline
\end{tabular}

TABLE IV

NUMERICAL ANALYSIS OF DIFFERENCES FROM TABLE II WHICH ARE STATISTICALLY SIGNIFICANT BY THE $\chi^{2}$ TEST

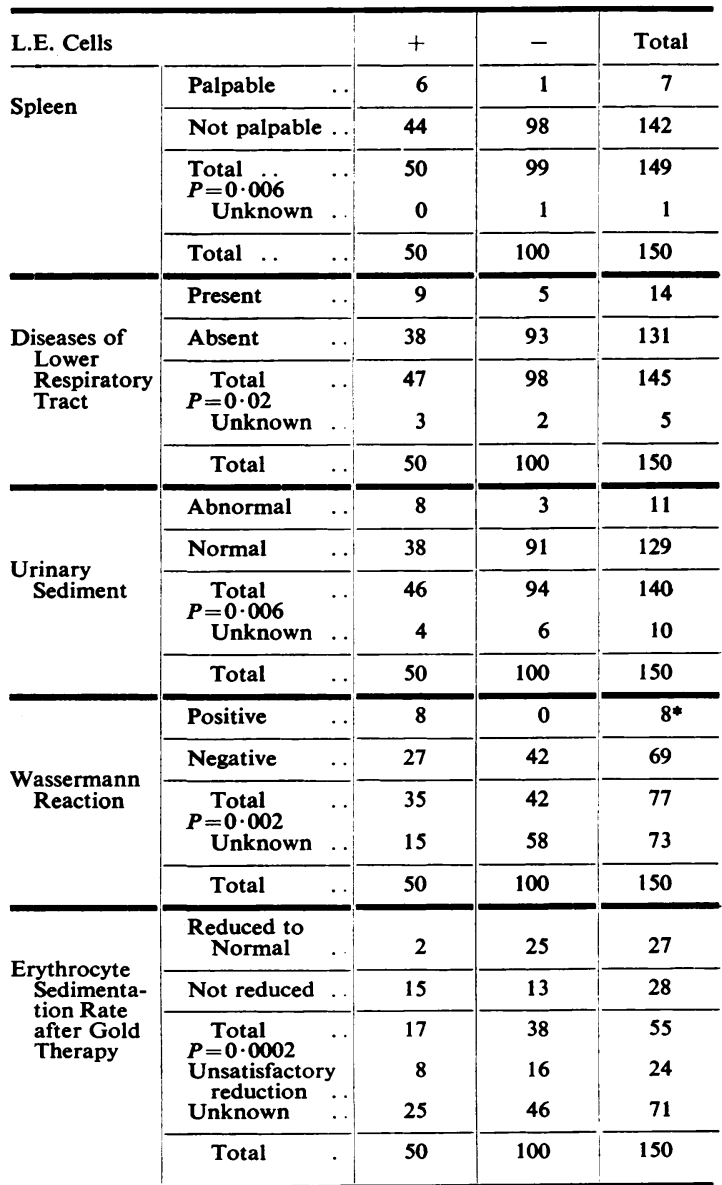

Wass. $\mathbf{R} .+32$

Wass. R. +$\} 6$
Mein. R. -$\} 6$ 
The results in Table $V$ are calculated by the method of Smirnov (1948).

Haemoglobin (Table V).-The first LE + column gives the cumulative numbers and the next column the cumulative percentages of regularly increasing haemoglobin values. The haemoglobin level of the LE+ patients is lower than that in the LE- group. The difference is statistically highly significant $(P=0.0004)$.

Erythrocyte Sedimentation Rate (Table V).-This was measured on the same day as the L.E.-cell examination. It is given in cumulative numbers and percentages. The difference is statistically significant $(P=0 \cdot 03)$. L.E. cells were found in five patients whose sedimentation rates were lower than $10 \mathrm{~mm}$. in the first hour (Westergren).

TABLE V

CUMULATIVE DISTRIBUTION OF HAEMOGLOBIN AND ERYTHROCYTE SEDIMENTATION RATE

\begin{tabular}{|c|c|c|c|c|c|}
\hline \multirow{2}{*}{ L.E. Cells } & & \multicolumn{2}{|c|}{+} & \multicolumn{2}{|c|}{ - } \\
\hline & & Cases & $\begin{array}{c}\text { Per } \\
\text { cent. }\end{array}$ & Cases & $\begin{array}{c}\text { Per } \\
\text { cent. }\end{array}$ \\
\hline $\begin{array}{l}\text { Percentage } \\
\text { Haemoglobin } \\
\text { (g.) }\end{array}$ & $\begin{array}{l}<46(7.4) \\
<51(8.2) \\
<56(9.0) \\
<56(9.8) \\
<61(10.6) \\
<66(11.4) \\
<71(11.4) \\
<76(12.2) \\
<81(13.0) \\
<86(13.8) \\
<91(14.6) \\
<96(15.4) \\
<101(16.2)\end{array}$ & $\begin{array}{r}3 \\
8 \\
11 \\
15 \\
32 \\
37 \\
40 \\
44 \\
44 \\
47 \\
48\end{array}$ & $\begin{array}{r}6 \cdot 2 \\
16 \cdot 7 \\
22 \cdot 9 \\
31 \cdot 2 \\
66 \cdot 7 \\
77 \cdot 1 \\
83 \cdot 3 \\
91 \cdot 7 \\
91 \cdot 7 \\
97 \cdot 9 \\
100 \cdot 0\end{array}$ & $\begin{array}{r}6 \\
15 \\
26 \\
39 \\
63 \\
78 \\
85 \\
87 \\
88\end{array}$ & $\begin{array}{r}6.8 \\
17.0 \\
29.5 \\
44.3 \\
71.6 \\
88.6 \\
96.6 \\
98.0 \\
100.0\end{array}$ \\
\hline
\end{tabular}

\begin{tabular}{|c|c|c|c|c|c|c|}
\hline & \multicolumn{6}{|c|}{$\begin{array}{l}\text { D. } \max .=66 \cdot 7-29 \cdot 5=37 \cdot 2 \text { per cent. (Smirnov } \\
\text { test) } P=0 \cdot 0004 \\
\text { Unknown } \quad 2\end{array}$} \\
\hline & Total & . & 50 & & 100 & \\
\hline $\begin{array}{l}\text { Erythrocyte } \\
\text { Sedimentation } \\
\text { Rate } \\
\text { (Westergren } \\
\text { mm./hr.) }\end{array}$ & $\begin{array}{rr}> & 100 \\
> & 80 \\
> & 60 \\
> & 50 \\
> & 40 \\
> & 30 \\
> & 20 \\
> & 10 \\
>\quad 0\end{array}$ & $\begin{array}{l}\ldots \\
\ldots \\
\ldots \\
\ldots \\
\ldots \\
\ldots \\
\ldots \\
\ldots\end{array}$ & $\begin{array}{r}4 \\
12 \\
21 \\
24 \\
29 \\
36 \\
42 \\
45 \\
50\end{array}$ & $\begin{array}{r}8 \cdot 0 \\
24 \cdot 0 \\
42 \cdot 0 \\
48 \cdot 0 \\
58 \cdot 0 \\
72 \cdot 0 \\
84 \cdot 0 \\
90 \cdot 0 \\
100 \cdot 0\end{array}$ & $\begin{array}{r}2 \\
9 \\
16 \\
22 \\
35 \\
56 \\
72 \\
83 \\
97\end{array}$ & $\begin{array}{r}2 \cdot 0 \\
9 \cdot 3 \\
16 \cdot 5 \\
22 \cdot 7 \\
36 \cdot 0 \\
57 \cdot 7 \\
74 \cdot 2 \\
85 \cdot 5 \\
100 \cdot 0\end{array}$ \\
\hline
\end{tabular}

D. $\max .=42 \cdot 0-16 \cdot 5=25 \cdot 5$ per cent. (Smirnov

\begin{tabular}{l|l|l|l|} 
Unknown & $0^{\text {test) } P=0.03}$ \\
\hline Total &. & 50 & \\
\end{tabular}

A reduction in sedimentation rate after a first course of gold therapy (Table IV), occurred in 25 out of 38 cases in the LE - group and in only two out of seventeen cases in the LE + group. $(P=$ 0.0002.) Unfortunately, the number of unknowns is high, and this result cannot therefore be applied to the whole group.

The occurrence of L.E. cells in rheumatoid arthritis can therefore be more or less confidently expected, but it is not possible to relate the findings of L.E. cells to a typical clinical picture.

\section{Discussion}

The majority of papers dealing with the specificityo of the L.E.-cell test have been discussed in the monograph by Harvey and others (1955). This test seems to be highly specific for systemic lupus? erythematosus, but is also positive in a certain percentage of cases of penicillin-hypersensitivity and in some patients treated with hydralazine. In addition L.E. cells have been found in individua patients suffering from a variety of diseases. Inss many of these, however, it is reasonable to assumes from the descriptions that the cells in question werenot true L.E. cells, but other inclusion bodies, mores or less resembling those originally described byo Hargraves. It is essential to adhere to his criteria and to exclude the presence of tartcells, erythro-cr phagocytosis, or other phenomena, such as those $e^{-}$ described by Lee, Michael, and Vural (1951) and Inderbitzin (1953). Some of these can be dis- $-\overrightarrow{0}$ tinguished with special staining techniques, as they do not contain nuclear substances. In nine of our $\vec{p}$

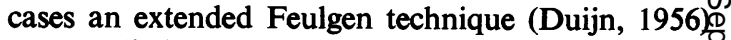
was applied; they were all positive, suggesting the presence of nuclear material.

In this study, L.E. cells were found in 17 per cent of 488 cases of rheumatoid arthritis. Because of the reproducibility, histochemical investigations, a adल negative results in control series, laboratory er can safely be excluded.

Three possible explanations of the diagnostics significance of this frequent occurrence of L.E cells in rheumatoid arthritis are discussed below:

(1) The test is not specific.-This seems unlikely as a control series yielded negative results: no L.E응 cells were seen in the slides of the cases listed in Table I, comprising 54 patients suffering from active tuberculosis, fourteen with chronic nephritis, and thirteen with discoid lupus erythematosus. Of $444^{\circ}$ cases suffering from various disorders, L.E. cells were found in nineteen: in eighteen of these the diagnosis of 3 systemic lupus erythematosus was compatible with the clinical picture. One patient was suffering from scleroderma; Volpé and Hauch (1955) also found L.E. cells in this disease.

Only two out of 119 patients, who were suffering from $\triangleright$ rheumatic disease but in whom the diagnosis of rheumatoid arthritis was not made when the L.E. test was done, had positive slides. In one, rheumatic nodules appeared 3 weeks later, and the other was suffering from ankylosing spondylitis with peripheralN arthritis. Therefore rheumatoid arthritis occupies $a$ unique place in this assumed non-specificity of the L.E.-cell phenomenon.

(2) The test is specific.-Every case with L.E. cells could then be diagnosed as suffering from systemic 
lupus erythematosus. This is a simple but not very satisfactory solution, as it seems hardly justified to classify a syndrome with unknown aetiology and unknown pathogenesis on the basis of an unexplained laboratory phenomenon. The following case-history illustrates the difficulty of accepting this theory for clinical reasons:

A 36-year-old woman visited the out-patient department for the first time in 1935 because of a migrating poly-arthritis with tenderness and swelling, involving the shoulders, elbows, wrists, hands, and knees. On further examination a chronic tonsillitis was found, but tonsillectomy was refused. The erythrocyte sedimentation rate was slightly increased (16 and $19 \mathrm{~mm}$. in the first hour). Analgesics were prescribed and her condition remained fairly satisfactory for the next 10 years. From 1945 onwards the polyarthritis deteriorated gradually and 1948 rheumatoid arthritis was diagnosed on the basis of clinical and $x$-ray findings. She greatly improved after tonsillectomy.

In June, 1953, she was seen by Dr. Fontein, to whom we are indebted for the following information:

For one year the arthritis has been progressive and the patient has complained of severe dizziness. She presented the typical picture of active rheumatoid arthritis with a flexion contracture of the left knee. A soft systolic murmur was heard over the apex and over the left border of the sternum. The dizziness remained unclassified. Laboratory data:

Erythrocyte sedimentation rate $39 \mathrm{~mm} . / \mathrm{hr}$.

Hb. 63 per cent.

Normal white blood count of 6,100 cells per c.mm. and a slight thrombopenia with 140,000 platelets.

A month later the patient developed a venous thrombosis of the left leg. As this was thought to be exceptional in rheumatoid arthritis, L.E.-cell preparations were made, which were repeatedly and strongly positive. In October, 1953, the patient was discharged in a greatly improved condition, the erythrocyte sedimentation rate being $12 \mathrm{~mm}$. $/ \mathrm{hr}$. The improvement was maintained when she was seen in April, 1954; the heart murmurs were unchanged and could not in themselves be taken to indicate a structural change. Soon afterwards she again became bedridden. On physical examination in April, 1956, the arthritis was not very active and no murmurs were heard. The L.E.-cell phenomenon was still positive.

If in such a case, with a 20 year's history of typical, clinical rheumatoid arthritis, the diagnosis has to be changed to systemic lupus erythematosus on the basis of L.E. cells after the occurrence of a thrombosis, every patient with the syndrome of rheumatoid arthritis should be suspected as a possible case of disseminated lupus erythematosus. This diagnosis does not indicate a disease entity, but only another clinical syndrome with unknown aetiology and pathogenesis.

(3) The results of the test are to be treated as purely descriptive.-About 17 per cent. of patients with rheumatoid arthritis show L.E. cells in preparations from peripheral blood. As a group they differ in certain respects from other cases of rheumatoid arthritis without L.E. cells. This difference concerns the spleen, the lower respiratory tract, the haemoglobin level, the urinary sedimentation, possibly the Wassermann reaction, the erythrocyte sedimentation rate, and the reaction to gold therapy.
At the present stage of our knowledge, this approach seems preferable to the other two; it is the least dogmatic and the most flexible, and by not giving a definite answer should stimulate further investigations.

It has been reported (Ishmael, 1955; Slocumb, 1955) that cortisone therapy increases the frequency of L.E. cells in rheumatoid arthritis. In our series there were only two among the 100 patients of the LE - group, who had received ACTH before the L.E.-cell examination. Of the fifty patients of the $\mathrm{LE}+$ group, there were seven who had been treated with either ACTH or cortisone, but in three of them L.E. cells had been found before the institution of hormone therapy. As no L.E.-cell preparations were made in the remaining four patients before treatment, it is not possible to evaluate the influence of hormone administration on the L.E. phenomenon. This reported increased frequency of $L$.E. cells in rheumatoid arthritis after cortisone treatment might be due to the fact that these patients were selected for treatment for the same reasons which classify them in our LE + group: a low haemoglobin value, a greatly increased erythrocyte sedimentation rate, or an unsatisfactory reaction to gold therapy.

\section{Summary}

L.E. cells were found in 17 per cent. of 488 cases of rheumatoid arthritis. This observation led to a statistical analysis of its clinical implications. The group with positive L.E.-cell phenomenon showed a higher frequency of splenomegaly, diseases of the lower respiratory tract, abnormal urinary sediment, anaemia, false positive tests for syphilis and a high erythrocyte sedimentation rate which failed to fall after a first course of gold treatment.

In individual cases of rheumatoid arthritis the positive L.E.-cell phenomenon was not related to a typical clinical picture.

We should like to acknowledge the support received from Prof. Dr. J. Mulder (Department of Medicine) and Prof. Dr. A. Querido (Department of Endocrinology and Metabolic Diseases) and their staffs; we are indebted to Dr. E. H. J. Warns and the staff of the Rotterdamsch Zeehospitium for the blood samples of patients with tuberculosis and to Dr. E. F. Drion (Statistics Department, T.N.O.) for statistical advice.

\section{REFERENCES}

Dubois, E. L. (1953). Ann. intern. Med., 38, 1265.

Duijn, P. van (1956). J. Histochem. Cytochem., 4, 55.

Fisher, R. A. (1954). "Statistical Methods for Research Workers" 12th ed., p. 96. Oliver and Boyd, Edinburgh.

Hargraves, M.'M., Richmond, H., and Morton, R. (1948). Proc. Mayo Clin., 23, 25.

Harvey, A. McG., Shulman, L. E., Tumulty, P. A., Conley, C. L., and Schoenrich, E. H. (1955). "Systemic Lupus Erythematosus" Williams and Wilkins, Baltimore. (Medicine (Baltimore), (1954), 33, 291)

Inderbitzin, T. (1953). J. invest. Derm., 20, 67. 
Ishmael, W. K. (1955). Discussion of McCoy, Patterson, and Freyberg (1955).

Kaposi, M. K. (1872). Arch. Derm. Syph. (Prag.), 4, 36.

Klemperer, P., Pollack, A. D., and Baehr, G. (1941). Arch. Path. (Chicago), 32, 569.

McCoy, F. W., Patterson, M., and Freyberg, R. H. (1955). of the Rheumatic Diseases, 14, 415 .

Lee, S. L., Michael, S. R., and Vural, I. L. (1951). Amer. J. Med., $10,446$.

Reifenstein, E. C., Reifenstein, E. C., Jr., and Reifenstein, G. H. (1939). Arch. intern. Med., 63, 553.

Slocumb, C. H. (1955). Discussion of McCoy, Patterson, and Freyberg (1955).

Smirnov, N. (1948). Ann. math. Statist., 19, 279.

Smirnov, N. (1948). Ann. math. Statist., 19, 279.
Volpé, R., and Hauch, J. T. (1955). Can. med. Ass. J., 72, 597.

Zimmer, F. E., and Hargraves, M. M. (1952). Proc. Mayo Clin., 27,424 .

\section{L'arthrite rhumatismale et le phénomène positif des cellules du lupus érythémateux}

\section{RÉSUMÉ}

Des cellules L.E. furent décelées dans 17 pour cent de 488 cas d'arthrite rhumatismale. Cette observation conduisit à une analyse statistique de ses implications cliniques. Le groupe au phénomène des cellules L.E. positif accusa une plus grande fréquence de splénomégalie, de maladies des voies respiratoires inférieures, de sédimentation urinaire anormale, d'anémie, de fausses réactions positives pour la syphilis, ainsi qu'une vitesse de sédimentation globulaire élevée qui ne diminua pas après la première étape du traitement aux sels d'or.

Dans des cas individuels d'arthrite rhumatismale, le phénomène positif des cellules L.E. ne se rapportait?्? à aucun tableau clinique typique.

La artritis reumatoide $y$ el fenómeno positivo de células del lupus eritematoso

Sumario

Células L.E. fueron encontradas en el 17 por ciento de 488 casos de artritis reumatoide. Esta observaciónllevó a una análisis estadística de sus implicaciones. clínicas. El grupo con el fenómeno de células L.E. $\overrightarrow{\vec{\omega}}$ positivo manifestó mayor frecuencia de esplenomegalia, $\vec{\omega}$ de enfermedades de las vías respiratorias inferiores, de sedimentación urinaria anormal, de anemia, de falsas reacciones sifilíticas así como una velocidad de sedi- mentación eritrocitaria alta que no bajó después de lậ primera serie de crisoterapia.

En casos individuales de artritis reumatoide, ein fenómeno positivo de células del lupus eritematoso nose relacionaba con ningún cuadro clínico típico. 